\title{
Leon Zawadowski
}

\section{Szkic z perspektywy osobistej}

Słowa klucze: lingwistyka funkcjonalna, logocentryzm ekspresyjny, logocentryzm wiedzocentryczny, psychocentryzm, de Saussure, Wittgenstein, Zawadowski.

Keywords: functional linguistics, expressive logocentrism, knowledge-centered logocentrism, psychocentrism, de Saussure, Wittgenstein, Zawadowski.

Profesor Leon Zawadowski, najwybitniejszy uczeń Kuryłowicza, nestor polskiego językoznawstwa, jest lingwistą-romanistą, ale nade wszystko teoretykiem języka. Rozwinął swą dojrzałą twórczość bezpośrednio po II wojnie światowej w wieku około 30 lat. Dwie pierwsze pozycje książkowe jego autorstwa to Zagadnienie teorii zdań względnych, 1948, i Constructions grammaticales et formes périphrastiques, 1959. Obie monografie mają trwałą wartość, pierwsza dla składni, zwłaszcza polonistycznej, druga dla pogranicza morfologii i składni, zwłaszcza romanistycznej. W latach pięćdziesiątych bardzo poważnym osiągnięciem naukowym była seria jego (głównie francuskojęzycznych) znakomitych artykułów teoretycznych w Biuletynie Polskiego Towarzystwa Językoznawczego; autor formułował tam założenia dotyczące 
wszystkich ważniejszych aspektów języka, będących przedmiotem zarówno językoznawstwa wewnętrznego, jak i zewnętrznego; fundamentalny zakrój ma jego roztrząsanie problemu znaczenia; ale wielce doniosłe były także jego myśli z zakresu komparatystyki i socjologii języka. W tymże Biuletynie opublikował poważną recenzję fundamentalnego dzieła U. Weinreicha Languages in contact. Za klasyczną należy uznać jego rozprawę pt. Rzeczywisty i pozorny wpływ kontekstu na znaczenie, 1951, której znajomość należała u nas kiedyś do rudymentów wykształcenia teoretyczno-lingwistycznego.

Po wielu latach, może także w związku z nieprzerwanym od 1969 roku pobytem Profesora za granica, w Kanadzie, obecność odbicia jego myśli w pracach językoznawczych powstających w Polsce jest mocno ograniczona. Jednakże praktycznie nie ma w Polsce językoznawcy, który by w taki czy inny sposób nie miał kontaktu z podstawowym, bardzo obszernym dziełem L. Zawadowskiego Lingwistyczna teoria języka (1966), w której autor dokonał rozwinięcia i scalenia swych refleksji i wizji teoretycznych. Niedawno Magdalena Danielewiczowa w obszernym opracowaniu (Danielewiczowa 2012) wydobyła zasługi Zawadowskiego we wdrażaniu w Polsce pożywnych owoców inspiracji Saussure'owskiej (niezależnie od pewnych różnic między poglądami mistrza genewskiego a poglądami mistrza wrocławskiego).

Nie mogąc w swoim krótkim wystąpieniu wchodzić we wszystkie szczegóły tez i argumentów autora w ich ogromnie bogatej panoramie poświęconej głównie mozolnemu krytycznemu budowaniu wszechstronnego instrumentarium pojęciowego, które miało służyć udoskonalonemu, niezmyłkowemu opisowi języka, powiem sumarycznie, że to dzieło, Lingwistyczna Teoria Języka (LTJ), które pojawiło się tuż przed wyjazdem uczonego za granicę, stanowiło swego rodzaju cytadelę dojrzewającego i już dojrzałego polskiego strukturalizmu językoznawczego, tak jak się on kształtował w poprzedzającym publikację mniej więcej czterdziestoleciu. Zawadowski oceniał przy tym krytycznie pewne publikacje spod znaku strukturalizmu. Do językoznawstwa propagowanego przez siebie lubił odnosić etykietę ,językoznawstwa funkcjonalnego"; mogło to przypominać sztandarowe hasło szkoły praskiej, choć podejście autora było całkowicie oryginalne i jedynie jakoś paralelne $\mathrm{w}$ stosunku do idei prażan.

Poważna analiza dorobku L. Zawadowskiego w jego całokształcie obejmującym również to, co autor stworzył później, za granicą, a więc obejmującym m.in. anglojęzyczną książkę z teorii języka wydaną w wydawnictwie 
Moutona, jest osobnym zadaniem, które mogłoby i powinno byłoby zostać wykonane na przykład w trybie przygotowania rozprawy doktorskiej lub habilitacyjnej. Nawet najskromniejszego substytutu takiej rzeczy nie jestem w stanie podać obecnie. Dlatego zestawię tylko kilka spośród głównych wskazań teoretycznych Profesora wraz z własnymi skrótowymi komentarzami o charakterze historyczno-porównawczym (przy czym opieram się zasadniczo na $L T J$ ), a ponadto zapoznam Państwa ze swym krótkim osobistym przypomnieniem pewnych ważnych wydarzeń związanych z działalnością Profesora w okresie przed rokiem 1968.

Oto więc, na początek, zarys cząstkowego, wybiórczego, zestawienia zasadniczych idei lingwistyczno-teoretycznych L. Zawadowskiego i ich charakterystyki. Ujmę rzecz w trzech punktach.

1. Bezpośrednim empirycznym przedmiotem badania nastawionego na uzyskiwanie autentycznych prawd ustalających to, co istnieje obiektywnie w języku, jest tekst jako perceptybilny ciąg foniczny. Ma on podlegać dwóm segmentacjom. Pierwsza, niezależna, segmentacja, którą autor nazywa ,inherentną” (inną nazwą jest ,analiza formalna”), polega na przydzielaniu okazów części ciągu do klas o wspólnych cechach i ustalaniu odpowiedniej gramatyki (powiedzielibyśmy, ,gramatyki drugiego szczebla rozczłonkowania”, czyli gramatyki wielkości czysto diakrytycznych) - przy rozumieniu ,gramatyki" jako systemu relacji kookurencyjnych. Drugi etap segmentacji polega na porządkowaniu ciągu tekstowego ze względu na zachodzenie jednostronnych implikacji z poprzednikami w postaci określonych inherentnych sekwencji w obrębie ciągu - stanowiących, w terminologii autora, ,znaczywo" (nie pokrywające się z całokształtem właściwości fizycznych odpowiednich „surowych” odcinków) - oraz z następnikami w postaci określonych klas elementów rzeczywistości zewnętrznej. Symbolem odpowiadającym tym implikacjom jednostronnym, który powtarza się niemal co kilka stron w tekście LTJ jest zapis ,ułamkowy” z literą T - od tekst - w ,liczniku” i literą R - od rzeczywistość - w „mianowniku”; obok tego symbolu funkcjonują relacje takich ,ułamków” i relacje samych przez się „T” zaznaczane dwukropkiem w układzie linearnym (np. $T: T$ ).

$\mathrm{Na}$ to odniesienie do rzeczywistości, odniesienie rozumiane całkowicie realistycznie, by tak rzec, optymistycznie, kładzie Zawadowski zasadniczy nacisk. Koresponduje to, zauważę, doskonale z pewnym aspektem wi- 
zji zawartej w Traktacie Wittgensteina (nawet jeżeli autor o tym filozofie nie wspomina), mianowicie $\mathrm{z}$ aspektem, który nazwałbym ,prawdocentryzmem". Przeciwstawia się autor natomiast idei immanentnej struktury czystych asymetrycznych różnic $d$ w u s tro nnych w ,znakach językowych”, tak jak je koncypował de Sausssure z jego zaakcentowaną niechęcią do korelacji wyrażeń z realnymi zjawiskami świata pozajęzykowego czy też pozatekstowego.

Spróbuję zestawić tę charakterystykę stanowiska Zawadowskiego w jego relacji do stanowisk Wittgensteina i de Saussure'a z wyznawaną przeze mnie trychotomią podstawowych poglądów na temat istoty języka czy też jego miejsca w Rzeczywistości. Trychotomia ta przewiduje trzy główne kontrastujące ze sobą (super)paradygmaty: ,„psychocentryzm : logocentryzm ekspresyjny : logocentryzm prawdo- lub, inaczej, wiedzocentryczny"; w tym zestawie wyróżniam ostatni paradygmat jako adekwatny, odrzucam natomiast dwa poprzednie jako nieadekwatne. Otóż Zawadowski, wraz z wczesnym Wittgensteinem, jest reprezentantem aprobowanej przeze mnie postawy wiedzocentryczno-logocentrycznej, w odróżnieniu od saussure'owskiego i późnowittgensteinowskiego logocentryzmu ekspresyjnego.

Jednoznacznie radykalnej, elokwentnej i wielce przekonywającej krytyce psychocentryzmu, który nazywa, zgodnie z długą tradycją, psychologizmem, Zawadowski poświęca wiele miejsca. Gdybym miał więcej czasu, $\mathrm{z}$ upodobaniem cytowałbym długie fragmenty świetnego ataku Zawadowskiego na ten wywołujący sprzeciw kierunek myślenia.

Mówi on tu też o de Saussurze jako (przynajmniej w jakimś stopniu) psychologiście; głównie chodzi mu o odniesienie przez genewczyka nazwy ,psychiczny” do obu stron „znaku językowego” (w sensie de Saussure’a). Myślę jednak, że od typowego psychocentryzmu reprezentowanego przez tradycyjny czy też szkolny (inaczej: filisterski) arystotelizm de Saussure był daleki: chodziło mu w jego, może trochę niefortunnym, wysłowieniu o konieczne wzniesienie języka jako takiego ponad zjawiska fizyczne i fizjologiczne, tak jak tego chciał przed nim Baudouin de Courtenay (w swej wczesnej twórczości nie popadający nawet w czysto słowny psychologizm); absolutna niezawisłość langage i langue od c z e g o kolw i e k, jaką widział de Saussure, przeczy jego możliwemu (pozawerbalnemu) psychocentryzmowi. Osobną sprawą jest realny kontrast jego logocentryzmu, jak go określam, ekspresyj- 
nego - z prawdocentryczną wersją logocentryzmu reprezentowaną przez autora Traktatu.

2. Zasadniczą różnicę między globalnym ujęciem języka przez Zawadowskiego a podobnie globalnym jego ujęciem w Traktacie i w Kursie upatrywałbym w podkreślanej przez Zawadowskiego, z nastawieniem polemicznym wobec de Saussure’a „bilateralistycznej” teorii wyrażeń, potrzebie niebilateralnego (a więc unilateralnego) podejścia do „znaku językowego”.

Jest $\mathrm{w}$ tym podejściu Zawadowskiego znowu coś podobnego do jednej z głównych idei Wittgensteina. Tej mianowicie, że do faktów językowych, mownych, dochodzi dzięki paralelizmowi dwóch realnych stanów rzeczy, z których jeden „odwzorowuje” drugi; dodajmy, że kluczowe miejsce zarówno w Traktacie, jak i w LTJ zajmuje sam nawet termin „odwzorowanie” (niem. Abbilden). Ta wspólna, głęboko antypsychocentryczna, nieugięcie obiektywizująca, tendencja Wittgensteina i Zawadowskiego jest w moim odczuciu czymś jak powiew orzeźwiającego, a nawet otrzeźwiającego, świeżego powietrza w całokształcie dziejowej refleksji nad językiem, refleksji często mocno skażonej, by tak rzec, „duchologią”, pojęciową promiscuitas, impresjonizmem.

Ale trzeba tu od razu dodać istotne zastrzeżenie. Wskazane przed chwilą dwa skorelowane stany rzeczy mają u Zawadowskiego charakter po obu stronach równie naturalistyczny i pozytywny. Podlegają one osobnym opisom w terminach klas okazów fizycznych, naprzód tekstowo-akustycznych, a następnie klas okazów o odpowiednio odmiennej naturze (w ostatecznym rozrachunku też fizycznej), np. minerałowych, roślinnych, artefaktowych, geograficznych itd., zawsze w takim układzie, że obecność cech charakterystycznych owych pierwszych klas jest warunkiem wystarczającym, ale by default nie koniecznym, obecności charakterystycznych cech klas przedmiotów rzeczywistości poza tekstami samymi (chodzi więc, jak już o tym mówiłem, o implikację jednostronną: ,[dom]” pełni rolę poprzednika w implikacji z obecnością klasy domów jako następnika, ale obecność okazów klasy 'dom' nie implikuje segmentu słownego [dom] ani jego okazów).

Otóż na swój sposób mamy tu do czynienia z odwróceniem Martinetowskiego pierwszego i drugiego szczebla rozczłonkowania: mamy naprzód niezależne twory czysto diakrytyczne, a potem ich korelacje (jednostron- 
no-implikacyjne by default $\mathrm{w}$ sensie przed chwilą objaśnionym) - z czymś zewnętrznym. Wiąże się to u Zawadowskiego z jego rozważaniem języka w pryzmacie różnych, jak je nazywa, ,systemów semantycznych” łącznie z „systemami bez gramatyki (tylko z „leksykiem”)”, rozważaniem podobnym do Saussure'owskiego „semazjologicznego” podejścia do języka. Oczywiście, język (jak go nazywa) „ekologiczny”, tzn. etniczny, odznaczający się charakterem uniwersalnym, $\boldsymbol{m a}$ u Zawadowskiego gramatykę, tzn. komponent niedowolnych kookurencji elementów. Ale jest to dla niego tylko rozbudowany system semantyczny, którego najgłębsza istota ma mimo wszystko tkwić już w korelacjach z klasami przedmiotów zewnętrznych - pojedynczych ,znaków” bez gramatyki, a więc „znaków” takich, jakie znamy z systemów prostszych, np. takich jak flagowa sygnalizacja w żegludze, a nawet (należy rozumieć) w postaci znaków izolowanych, których przykładem (pozwalam sobie wskazać własną ilustrację) może być obrazek trupiej główki na słupach linii wysokiego napięcia. Powtórzmy: najgłębsza istota języka ma być wspólna językowi naturalnemu, z jednej strony, a tym prostym znakom czy systemom znaków, z drugiej strony.

Jest to stanowisko tylko powierzchownie podobne do Saussure'owskiego. Podobne jest ono mianowicie jedynie w aspekcie umieszczenia języka przez obu uczonych - w szerszym ,świecie (różnorodnych) systemów znakowych". Co się tyczy de Saussure’a, w gruncie rzeczy chodziło mu po prostu o podtrzymanie tradycyjnego nazywania wyrażeń językowych „znakami” (por. pisma św. Augustyna i tylu innych; z mniejszościową opozycją reprezentowaną np. przez Humboldta, a w XX w. np. przez Schelera, Kainza). W konsekwencji de Saussure uznawał, sugerowane w nazwie „znaki”, pokrewieństwo języka wobec np. znaków drogowych, dystynkcji wojskowych, herbów itd. Trzeba jednak pamiętać o tym, z jak wielką mocą podkreślał de Saussure absolutną swoistość języka naturalnego - jako systemu pozbawionego jakiejkolwiek szczególnej motywacji „społeczno-zadaniowej”; trzeba też pamiętać o wydobyciu przez niego konstytutywnej dla języka roli układów proporcjonalnych, syntagmatyczno-paradygmatycznych, implikujących wielość elementów. Zawadowski natomiast poszukuje wyjaśn i e ni a, jak o tym przed chwilą mówiłem, samego fenomenu mowy poprzez znalezienie tego, co ma jej być wspólne ze zjawiskami prostszymi. O proporcjach zaś mówi Zawadowski w LTJ tradycyjnie jako o „potencji analogicznej” w tworzeniu kolejnych kookurencji, kiedy już takowe w ogóle (w systemie z gra- 
matyką) występują; nie umieszcza sprawy proporcji, w odróżnieniu od de Saussure'a, w centrum obrazu języka naturalnego (tak jest w każdym razie, podkreślam, w LTJ).

Powiedzmy teraz: prezentacja Zawadowskiego rodzi pewien problem. Jest to problem sposobu zdania sprawy z pojawienia się tych oto elementarnych faktów, bez których nie ma języka naturalnego: „ktoś powiedział coś”, a zwłaszcza, wcześniej jeszcze: „ktoś powiedział komuś, $\dot{z} \boldsymbol{e}$ tak a tak”. Przyjmijmy oto, że Zawadowskiego ,jednostronna implikacja by default" zachodzi tam, gdzie można zaobserwować układ o kształcie następującym: „strój łowicki $\rightarrow$ Łowiczanka”. Ale ten strój nie mó $\boldsymbol{w} \boldsymbol{i}-$ w literalnym, niemetonimicznym lub niemetaforycznym, sensie - o wiadomym regionalnym pochodzeniu osoby ubranej we wskazany sposób. Może się co najwyżej zdarzyć, że ktoś, widząc wiadomy strój, w zwykty sposób powie: „ta pani to Łowiczanka", lub nawet $w$ zwykty sposób powie, że ta pani to Łowiczanka. Więc wciąż powraca pytanie: jak współobecność ciągu fonicznego i fragmentu rzeczywistości ma doprowadzać kogoś do tego, że zaczyna ni mniej ni więcej, tylko $\boldsymbol{m} \boldsymbol{o} \boldsymbol{w} \boldsymbol{i} \boldsymbol{c}$ (o tym fragmencie rzeczywistości)?

Ponadto trzeba poczynić istotną uwagę następującą: operacje ustalania korelacji według schematu Zawadowskiego - z wcześniejszym opisem fonologicznego składu morfemów - wymagają już obecności pełnokrwistego języka, w którym się to ustalanie korelacji wraz z wcześniejszym inherentnym opisem morfemów ma dokonywać. Pierwotność Martinetowskiego pierwszego szczebla rozczłonkowania właśnie jako pierws zego jest niezbywalna. Sam op is strony formalnej (,strony formalnej” w sensie Zawadowskiego) wymaga już, powtórzmy, całego normalnego języka. Zdawał z tego sprawę w swym „różnicowo-bilateralnym” ujęciu „znaków” de Saussure. Zdawał z tego sprawę również Wittgenstein w Traktacie, por. zwłaszcza jego tezę 4.1241: „Form nie można odróżniać od siebie przez to, że się powie, iż jedna ma tę, a druga tamta własność [podkr. moje - AB]. Zakładałoby to bowiem, że jest sens orzekać obie własności o obu formach”. Wittgenstein ma rację: mamy tu do czynienia z rzeczami apriorycznymi (z kantowskim „syntetycznym a priori").

Rozwiązanie dylematu przynosi, w ślad za Leibnizem, Traktat z jego, jak to nazywam, ikonizmem strukturalnym jako sposobem ujęcia zdania (w bazie języka). Otóż ten ,ikonizm strukturalny” implikuje decydujące uwzględnienie roli składni w języku, a więc pierwotność, by pozostać przy 
terminologii Zawadowskiego, „systemu semantycznego” bardziej skomplikowanego, a nie uproszczonego (w zgodzie także ze wskazaniami Bühlera, którego prace skądinąd Zawadowski uwzględniał i cenił); dalej, implikuje on uwzględnienie kontrastów kontradyktorycznych jako fenomenu kluczowego; i wreszcie, implikuje on stanowcze odrzucenie Fregowskiego potraktowania zdania jako nazwy, mianowicie nazwy Prawdy lub Fałszu. Ani de Saussure, ani Zawadowski tego rodzaju pełnego rozwiązania nie podał. Ale de Saussure w każdym razie dobrze się zasłużył teorii języka, windykując w ogólny sposób sprawę kontrastywności/negatywności. Zawadowski słusznie zakwestionował absolutyzacje „negatywizmu” u de Saussure’a; jednakże wagi kierunku inspiracji związanej z tym „,negatywizmem”, jaką oferował mistrz szwajcarski, moim zdaniem, nie docenił; tego zaś, co w tej mierze prezentował Wittgenstein, w sposób zasadniczo doskonalszy niż de Saussure, w ogóle nie uwzględnił.

(Dorzucę w tym miejscu, nawiasowo, przypomnienie, że z dylematem, który można skrótowo nazwać hasłem „strój łowicki a wypowiedź”, miałem do czynienia w swej książce ściśle równoległej czasowo w stosunku do LTJ, bo opublikowanej w roku 1966 [Semantyczne pojęcie liczebnika ...]; moje ujęcie sprawy było odmienne od przypomnianego przed chwilą ujęcia Zawadowskiego. Odwoływał się do mojego ujęcia w r. 1975 M. Grochowski w swej książce o środku czynności, a później, wprowadzając własne modyfikacje, A. Weinsberg w swym Językoznawstwie ogólnym.)

3. Nieprzemijającą wartość ma Zawadowskiego płomienna, rzec można, obrona badań semantycznych zawarta w końcowych partiach LTJ oraz jego program takich badań (realizowany przez niego, niestety, w ograniczonej mierze). Z tą obroną semantyki wiąże się w jego wypowiedziach po stokroć słuszny krytycyzm wobec przedchomskiańskiego dystrybucyjnego deskryptywizmu amerykańskiego (choć o Chomsky’m Zawadowski nie mówił). Jego wskazania metodologiczne w zakresie semantyki, na przykład w sprawie hasła „wieloznaczność”, nie mają sobie równych w naszej, i chyba nie tylko naszej, literaturze. Jego roztrząsania wokół rodzajów wypowiedzi, wokół predykacji i atrybutywizacji, z tak delikatnymi, wnikliwymi ekskursami, jak, dla przykładu, ten poświęcony jednemu, rzeczywiście interesującemu, wyrazowi wara, dalej, z wydobyciem przez niego nadrzędnych zdaniowych semantycznych operacji „sterujących”, niesprowadzalnych do jakichkolwiek 
wyliczeń elementów znaczeniowych (co jest jakoś pokrewne ideom ,pokazywania” czy „uwidaczniania się” głoszonym przez Wittgensteina), wreszcie z w pełni jasną świadomością wielkich rozmiarów leksykalizacji słowotwórczej i frazeologicznej, mogą być wciąż źródłem ożywczej inspiracji.

Co się tyczy tej ostatniej sprawy, sprawy leksykalizacji, to stała się ona potem, jak wiadomo, przedmiotem mojego szczególnego hobby, w którego uprawianiu popełniałem, niestety, sporo błędów. Dodajmy w tym związku, że wprawdzie takie tezy Zawadowskiego, jak ta o ,prawie gramatycznym” dla pojedynczej relacji ne i pas we francuskim, mogą nasuwać myśl o zaniedbaniu przezeń idei leksykalizacji, ale że autor, w moim przekonaniu, dobrze rozumiał faktyczną jedność, by odnieść się do przed chwilą podanego przykładu, wyrażenia francuskiego, chciał natomiast odnotować to, co tak czy inaczej trzeba zarejestrować w dziale, nazwijmy to w ten sposób, „składni wewnętrznej" jednostek języka. Tą mikroskopowo zajęła się M. Danielewiczowa w Verba polona abscondita, 2005 (w moim przykładzie rozważanego przez Zawadowskiego franc. ne ... pas chodzi o dotyczący owej „,kkładni wewnętrznej" wielki problem wyrażeń nieciągłych, któremu główna autorka Verbów, w tych szerszych ramach „składni wewnętrznej”, poświęciła wiele uwagi; oczywiście uczonym wyróżniającym się w badaniach tego typu jest M. Grochowski).

Wszystkie poruszone tu zespoły roztrząsań Zawadowskiego, a pewnie również liczne dalsze, są wciąż żywo aktualne. Osiągają w wielu miejscach rangę najwyższą. Trzeba wracać do ich czytania. Na przykład wiele możliwych korzystnych inspiracji kryje się w jego obszernym przeglądzie faktów kontekstualnych i konsytuacyjnych, które trzeba uwzględnić w opisie i w podziale, czy też taksonomii, wypowiedzeń jako całości (taki przegląd autor LTJ przedstawił m.in. w ostatnim rozdziale książki).

Przechodzę do zapowiedzianego przypomnienia istotnych punktów działalności Profesora przed rokiem 1968.

Po wojnie Profesor Zawadowski znalazł się we Wrocławiu. W Uniwersytecie Wrocławskim był kierownikiem Katedry Językoznawstwa Ogólnego, w pewnym okresie także dziekanem wydziału. Środowisko tamtejsze nie sprzyjało twórczości znakomitego badacza i teoretyka. Po prostu zasób kadrowy filologii wrocławskiej był dość wątły; m.in. Jerzy Kuryłowicz znalazł się w Krakowie, na Uniwersytecie Jagiellońskim. 
Jednakże wyróżniający się intelekt Leona Zawadowskiego nie mógł pozostać niezauważony. Jego prace promieniowały na cały kraj. Szczególnym środowiskiem, które zainteresowało się wrocławskim potencjałem myślowym reprezentowanym przez niego i postanowiło szukać tam dla siebie pożywienia, było środowisko Instytutu Badań Literackich skupione głównie wokół M. R. Mayenowej, z takimi osobami jak Z. Florczak, Z. Kopczyńska, A. Wierzbicka i in. (wymieniam tylko przykładowo); do tego środowiska dołączyła część środowiska polonistyki i lingwistyki warszawskiej (wymieniłbym tu H. Kurkowska, A. Weinsberga, T. Buch, J. Puzyninę, R. Grzegorczykową, E. Janus, [w wyróżniony sposób] S. Karolaka, który był głównym animatorem przedsięwzięcia, o którym za chwilę). Do Zawadowskiego zaczęto podróżować. Powstała w tym związku inicjatywa umożliwienia większej liczbie warszawiaków kontaktu z mistrzem wrocławskim poprzez w miarę systematyczne spotkania seminaryjne w Warszawie. Zawadowski chętnie na to przystał, bo był spragniony przekazywania większemu gronu osób idei i pryncypiów metodologicznych, jakie wyznawał i ważył wysoko jako niezbędny budulec Nauki, którą (mówiąc patetycznie, ale adekwatnie) miłował. Tak zaczęły się w r. 1963 przyjazdy Profesora do Warszawy. Posiedzenia wykładowo-seminaryjne (odbywane, o ile wiem, w gmachu Wydziału Geologii przy ul. Żwirki i Wigury) gromadziły wiele osób. Profesor traktował tę działalność z wielką powagą; sprawdzana była nawet obecność uczestników. Prawą ręką Profesora stała się Anna Wierzbicka, wydoktoryzowana w IBL-u w r. 1963 (w wieku 25 lat). Była bardzo przejęta nauczaniem Zawadowskiego; wyraźny jego wpływ jest widoczny w jej książce z r. 1967 O języku dla wszystkich. W późniejszym okresie, już kiedy oboje byli za granica, miała jeszcze z nim korespondencyjne (australijsko-kanadyjskie) kontakty. Ale już wcześniej obrała inny, własny, paradygmat naukowy i ich współpraca praktycznie nie miała kontynuacji (czego, jak się zdaje, Zawadowski żałował).

Sam nigdy nie byłem na jego seminariach. Trudno jest mi właściwie powiedzieć, dlaczego. Bo kiedy pracowałem nad swą rozprawą doktorską na temat rosyjskiej prefiksacji czasownikowej, w okresie 1954-1959 (obrona odbyła się w r. 1960), obok prac szkoły kopenhaskiej (odbyłem w r. 1959 wizytę w Kopenhadze i nawet starałem się o przyjęcie przez L. Hjelmsleva, co okazało się jednak niemożliwe ze względu na stan zdrowia mistrza), podstawowym oparciem teoretycznym dla mnie były właśnie dzieła Zawadowskiego. (Z wielkim niesmakiem przyjmował to prof. W. Doroszewski; w czasie mojej 
obrony doktorskiej zabrał głos głównie po to, by poddać krytyce pewne sformułowania z książki L. Zawadowskiego o zdaniach względnych, sformułowania, które nie miały żadnego bezpośredniego odniesienia do spraw morfologicznych, jakimi zajmowałem się w swej rozprawie, ani też do samego jej tekstu, poza tym faktem, że tekst rozprawy zawierał przywołanie Zawadowskiego jako autorytetu.) Mogę tylko dodać, że w bardzo ważnym początkowym okresie działalności warszawskiego seminarium Zawadowskiego, mianowicie w r. akad. 1963-1964, przebywałem na stażu naukowym w Moskwie, przygotowując swą rozprawę habilitacyjną, nad którą praca trwała jeszcze w latach 1965-1966 (kolokwium habilitacyjne miałem w listopadzie 1966 r.); te wydarzenia mogły stanowić pewną przeszkodę w moim przyłączeniu się do grona jego słuchaczy.

Skoro już powiedziałem o swoim zadłużeniu naukowym wobec Leona Zawadowskiego, to uzupełnię tę informację zwróceniem uwagi na fakt, że ważne dla mnie były nie tylko rzeczowe wywody autora, lecz może w nie mniejszej mierze to, co nazwałbym jego Stylem naukowym przez duże S, na który składały się nade wszystko: uparta orientacja na globalne porządkowanie terenu pojęciowego, niepowierzchowne problematyzowanie obiektów badania, nieustępliwa, wytrwała drażliwość w analizie, klarowność wykładu, brak obojętności emocjonalnej wobec przedmiotu połączony z pełną rzeczowością w wykładzie. Lektura jego prac poruszała mnie żywo. Propagowałem je; dla przykładu podam, że jego obszerny artykuł o znaczeniu morfemu przetłumaczyłem $\mathrm{z}$ francuskiego na rosyjski i tłumaczenie przekazałem zaprzyjaźnionemu prof. T. P. Łomtiewowi z sugestią wykorzystania tekstu w jego środowisku moskiewskim.

Tak żywe kontakty środowiska warszawskiego z L. Zawadowskim przyczyniły się do tego, że Profesor zaczął myśleć o stałej pracy w Warszawie, bodajże wraz z przeniesieniem się do stolicy. Opór, z jakim się spotkał ten pomysł na Uniwersytecie Warszawskim, spowodował, że żadnego dalszego ciągu sprawa nie miała. Była to rzecz godna ubolewania, bo udział Profesora w pracach filologii warszawskiej byłby wielce ożywczy. W r. 1968 Zawadowski wyjeżdża na pobyt stypendialny do Ameryki. W r. 1969 rezygnuje z powrotu do Polski. Z pewnym trudem uzyskuje pracę w Kanadzie. W nowym usytuowaniu się Profesorowi bardzo pomagał R. Jakobson (mimo swego dość niechętnego stosunku do Profesora). 
Jeżeli chodzi o moje osobiste kontakty z Profesorem Zawadowskim, to ograniczyły się one właściwie do trzech spotkań. Powiem o nich na zakończenie.

W roku 1964 wziąłem udział we wrześniowej wielkiej konferencji międzynarodowej w Magdeburgu pn. Zeichen und System der Sprache (z serii pod tą samą nazwą). Uczestniczył w niej L. Zawadowski; rozmawiałem $\mathrm{z}$ nim w kuluarach. Nie prezentowałem tam żadnego referatu, ale postanowiłem zabrać głos w jednym z głównych punktów programu. W swym wygłoszonym po angielsku wystąpieniu prezentowałem niektóre ze swych przemyśleń teoretycznych z okresu swojego pobytu w Moskwie (1963-1964). Kiedy przekroczyłem nieco czas przeznaczony na głos w dyskusji, przewodniczący przerwał mi; prosiłem o parę dodatkowych minut; przewodniczący zapytał zgromadzenie o to, czy się na to zgodzi; wówczas wystąpił prof. Zawadowski i podtrzymał moją prośbę. Po paru minutach, jakie mi przyznano, zamknąłem swe wystąpienie.

W roku 1966 obaj uczestniczyliśmy w pamiętnym sympozjum semiotycznym w Kazimierzu n. Wisłą. W swym wystąpieniu krytycznym w stosunku do R. Jakobsona, osoby absolutnie centralnej w tym zgromadzeniu, mówiłem o konieczności rygoryzmu w odniesieniu do pryncypiów proporcjonalizmu i wskazałem jako nauczyciela i mistrza w tym zakresie na L. Zawadowskiego. Wielki uczony zareagował bardzo ostro. Potem, przy obiedzie, a może przy śniadaniu, łagodził sytuację, demonstracyjno-pojednawczo podchodząc do mnie i nawiązując przyjazną rozmowę; była ona kontynuowana nocą w tzw. Piekiełku (w Domu Dziennikarza, który gościł konferencję), z odpowiednim akompaniamentem płynnym (przebojem była wówczas polska śliwowica), akompaniamentem hojnie aplikowanym przez Jakobsona (pod nieobecność Krystyny Pomorskiej, skądinąd będącej również uczestniczką tej wielkiej imprezy).

Zapewne było to w roku 1967, kiedy prof. Zawadowski został zaproszony na zebranie filozoficzno-semiotyczne na Wydziale Filozoficznym UW (myślę, że było ono animowane przez prof. J. Pelca). Miał tam wyłożyć swe główne idee na temat języka i językoznawstwa. Oczywiście byłem obecny na tym posiedzeniu. Prelegent głosił swe tezy z wielkim wigorem. Jedną z nich, szczególnie interesującą filozofów, była ogólna teza naukoznawcza, zgodnie z którą nauka prezentuje w swych zdaniach rzeczy o różnych atrybutach, ale na pewno musi należeć do nich prawdziwość; nauka ma podawać prawdy; 
oczywiście musi się to stosować także do językoznawstwa. Te wypowiedzi Profesora wywołały dość zaognioną dyskusję, bo filozofowie nie godzą się na ogół na tego rodzaju prostolinijność w kwestii prawdy. Prof. Zawadowski był wyraźnie niezadowolony, zgoła poirytowany, i dość dramatycznie pytał, czy oponenci rzeczywiście chcą w ogóle nie wspominać o relacji prawdziwości tam, gdzie się mówi o nauce. Wówczas filozof prof. Marian Dobrosielski (późniejszy ambasador PRL w Londynie, a także osoba znana nie najlepiej z wydarzeń 8 marca 1968 roku na dziedzińcu Uniwersytetu Warszawskiego), pragnąc złagodzić spór, powiedział pojednawczo, ale też z odcieniem delikatnej ironii: „Sprawa zdań prawdziwych z pewnością musi być widziana przez uprawiających naukę; kłopot jest tylko ten, że się nie wie, które to mianowicie zdania są prawdziwe”. Była to uwaga, ogólnie rzecz biorąc, sensowna, ale na pewno nie zamykała ona sprawy. Bowiem prawdocentryzm, jaki Zawadowski reprezentował - reprezentował tak, jak rzeczy widział - jest po prostu elementarnym necessarium scientiae.

W moim rozumieniu po Baudouinie de Courtenay i Kuryłowiczu największy talent lingwistyczno-teoretyczny, już wśród Polaków z początku $\mathrm{XX}$ wieku, z której to doby pochodzi, trzeba przyznać, spore grono innych wybitnych językoznawców-teoretyków, by wspomnieć choćby Milewskiego, Heinza, Safarewicza, Doroszewskiego, Stiebera, Rysiewicza, Tokarskiego, Zabrockiego, przypadł w udziale właśnie Leonowi Zawadowskiemu.

Prześlijmy Mu głęboki pokłon, dziękczynienie i gorące życzenia dobrego zdrowia.

\section{Bibliografia}

BogusŁawski A., 1966, Semantyczne pojęcie liczebnika i jego morfologia w języku rosyjskim, Wrocław: Ossolineum.

BogusŁawski A., Danielewiczowa M., 2005, Verba polona abscondita. III sonda stownikowa. Warszawa: Elma Books.

Danielewiczowa M., 2012, Dziedzictwo Ferdynanda de Saussure'a w jednym z nurtów polskiej semantyki, w: K. Petryk (red.), Strukturalizm w Europie Środkowo-Wschodniej, Warszawa: IBL PAN, s. 340-352.

Grochowsкi M., 1975, Środek czynności w strukturze zdania. Narzędzie, substancja, materiał, Wrocław: Ossolineum.

SAussure DE F., 2002, Kurs językoznawstwa ogólnego, Warszawa: Wydawnictwo PWN. 
SAussure de F., 2004, Szkice z językoznawstwa ogólnego, Warszawa: Dialog.

WeinsBerg A., 1983, Językoznawstwo ogólne, Warszawa: Państwowe Wydawnictwo Naukowe.

Wierzbicka A., 1967, O języku dla wszystkich, Warszawa: Wiedza Powszechna.

Wittgenstein L., 1970, Tractatus logico-philosophicus, Warszawa: Państwowe Wydawnictwo Naukowe.

ZAWADOWSKi L., 1948, Zagadnienie teorii zdań względnych, Wrocław: Ossolineum.

ZaWADOWSKi L., 1951, Rzeczywisty i pozorny wpływ kontekstu na znaczenie, Sprawozdania Wrocławskiego Towarzystwa Naukowego 4, 1949, Dodatek 2, s. 1-18.

ZaWADOWSKi L., 1959, Constructions grammaticales et formes périphrastiques, Wrocław: Ossolineum.

Zawadowski L., 1966, Lingwistyczna teoria języka, Warszawa: Państwowe Wydawnictwo Naukowe.

\section{Leon Zawadowski. A Draft Portrait from a Personal Perspective}

( su m mary)

The author, first, reminds the Reader of the main points of Leon Zawadowski's scholarly career, second, calls the Reader's attention to some of the principal linguistic-theoretical tenets of his works, third, offers an outline of certain events in his pedagogical activity, in particular, as a visiting professor in Warsaw (in the midsixties), fourth, presents personal reminiscenses of encounters with Zawadowski at, roughly, the same time, and reports on certain facts concerning the influence that Zawadowski's writings had on his own work in the fifties and sixties.

The remarks on Zawadowski's contribution on the theory of language encompass: a short presentation of the fundamental linguistic-theoretical ideas outlined by Zawadowski, a high appraisal of the weight and style of his work, and a comparison of his theoretical approach with that of Wittgenstein as the author of the Tractatus, as well as with de Saussure's works. Both Wittgenstein and Zawadowski are classed among proponents of the knowledge-centered logocentrism in the theory of language (which is a position the author endorses), as opposed to de Saussure's and the later Wittgenstein's „expressive logocentrism”. Certain doubts are raised on account of several claims made by Zawadowski, in particular, on account of his claim of the necessity of a unilateral approach to so-called „linguistic signs" in its contrast to de Saussure's and Wittgenstein's ideas of the primordial status of bilateral units of language (as emerging from Martinet's „first level of (linguistic) articulation”). 